\title{
An Empirical Investigation of the Profitability Anomaly in the Indian Stock Market
}

\author{
Sanjay Sehgal, \\ Professor of Finance, Department of Financial Studies, \\ University of Delhi, India \\ Srividya Subramaniam(corresponding author), \\ Assistant Professor, Department of Economics, \\ SGTB Khalsa College, University of Delhi, India \\ E-mail: srividyadse@gmail.com
}

Received: Nov. 28, 2012 Accepted: December 10, 2012 Published: December 10, 2012

doi:10.5296/ajfa.v4i2.2777 URL: http://dx.doi.org/10.5296/ajfa.v4i2.2777

\begin{abstract}
This study examines the profitability anomaly for the Indian stock market using data for 493 companies on the BSE from January 1996 to December 2010. A negative relation between profitability and returns is empirically confirmed which is in contrast to prior research for mature markets. Further the observed relationship is robust to choice of profitability measure. The findings can be explained by the fact that more profitable firms tend to give higher dividend payouts and are therefore perceived to be less risky by investors resulting in lower returns. A positive relationship between profitability and payouts and a negative relationship between payouts and beta is obtained confirming our argument. The three factor Fama French model is able to explain returns on profitability sorted portfolios which was not fully explained by CAPM. Thus the profitability anomaly does not pose serious challenge to asset pricing in the Indian context. Our findings have strong implications for academicians as well as portfolio managers. The study contributes to equity market anomaly literature especially for emerging markets.
\end{abstract}

Keywords: Profitability, Dividend payouts, Beta, CAPM, Fama French model JEL code: C22, C33, G12, G14, G15 


\section{Introduction}

The literature on stock market anomalies is extensive and growing. Schwert (2003) defines anomalies as empirical results which are inconsistent with maintained theories of asset pricing. The CAPM which posits a positive and linear relation between beta and security returns was the accepted paradigm in the finance literature for a long time. However in the late 1970s, empirical work appeared that exposed the shortcoming of the CAPM. It was observed that that much of the variation in expected return is unrelated to market beta and various company characteristics could affect stock returns viz. size, book to market equity, earnings to price, past returns, leverage and momentum (Fama \& French, 1992) ${ }^{1}$.It was then well established that beta is inadequate to explain returns and thus there is need to develop multifactor asset pricing models. Fama and French (1993) developed a three-factor model for expected returns, which suggests that expected returns on a portfolio in excess of the risk-free rate are explained by sensitivity to market, size and value factors. The additional risk factors i.e. size and value are firm specific, yet they have proven to have an impressive explanatory power in explaining major anomalies of the CAPM for instance size, book to market, earnings to price, leverage.

However recent studies have found that even the Fama and French (1993) model is not without weaknesses. For instance, the model fails to explain returns on portfolios sorted on momentum (Fama \& French, 1996), accruals (Sloan, 1996), net stock issues (Loughran \& Ritter, 1995), (Ikenberry, Lakonishiok \& Vermaelen, 1995)) and profitability (Fama \& French, 2008). Fama and French (2008) point out that the model fails to explain returns on portfolios sorted on accruals, momentum and net stock issues in all size groups.

Asset pricing anomalies primarily momentum, accruals and net stock issues have been heavily researched for the developed capital markets. It is the profitability anomaly which is comparatively less explored. Existing literature on profitability anomaly establishes a positive relationship between profitability and returns. Haugen and Baker (1996) find more profitable firms have greater expected returns. They construct a model of expected returns which includes various accounting, market and past return variables and report that even after controlling for these variables more profitable firms tend to have greater expected returns. They relate profitability of a firm to its growth potential and posit that currently profitable firms have greater potential for future growth. This indicates the probability for faster (slower)-than-average future growth in a stock's earnings and dividends. Cohen, Gompers and Vuolteenaho (2002) also find that more profitable firms provide higher average stock returns. Fama and French (2006) conclude that given BM and expected investment, higher expected profitability implies higher expected returns. Fama and French (2008) report that the profitability anomaly exits only in the case of small stocks. In this case they find a positive relation between profitability and returns and presence of significant hedge returns although the hedge portfolio returns are nonexistent in the case of big stocks, tiny stocks and market as a whole. Fitzpatrick and Ogden (2009) find that the lowest future returns are associated with the lowest profit quintile and vice versa. Artmann, Finter and Kempf (2011)

\footnotetext{
Banz (1981),Stattman(1980), Basu (1983), Bhandari (1988), De Bondt and Thaler, $(1985,1987)$ and Jegadeesh and Titman (1993).
} 
find average returns increase as one moves from low profitability portfolios to high profitability portfolios.

A possible explanation for the positive relation obtained by the above studies could be that they visualise profits as the reward for growth and innovation, which exposes entrepreneurs to greater risk thus resulting in higher returns. This explanation is justified if we examine profitability from the firm's point of view. The firm might have borne higher operating or financial risk in managing its operations and profits could be regarded as the reward for risk bearing. Nevertheless the entire analysis of stock market anomalies has to be carried out from the perspective of the investor who is in pursuit of trading strategies which can generate positive alphas. We thus purport to explain the existence of the profitability anomaly from the latter's point of view as follows. If a firm is relatively more profitable then investors perceive it to be relatively less risky and are hence are willing to accept low returns. This would be a counter argument to the existing explanation to the profits as compensation for bearing higher risks.

To elucidate our point we hypothesise that risk (measured by beta) and share values are linked to payouts in form of dividends. Corporate profits earned by firms may be either retained and reinvested by the firm or paid out to shareholders as dividends. According to Amidu and Abor (2006), "profits have been regarded as the primary indicator of a firm's capacity to pay dividends". Pruitt and Gitman (1991) show that current and past year's profits are important in influencing dividends payments. Yiadom and Agyei(2011) show significant positive association between dividend policy and profitability. Aivazian, Booth and Cleary (2003) find that for emerging markets (including India) high profits tend to mean high dividend payments. Given that higher profitable firms pay higher dividends we next explore the influence of corporate dividend policies on stock prices. The bird in the hand theory (Gordon, 1963) argues that investors prefer a dividend today to a highly uncertain capital gain from future investments tomorrow. Hence investors value high payout firms more highly. Shefrin and Statman (1984) develop a behavioural theory in which they show that investors want dividends because of self control and due to choices made under uncertainty. Their theory suggests that some investors would be willing to pay a premium for dividends due to self control reasons or wish to avoid regret. Investors finance consumption out of dividends and do not want to dip into capital. Also there is empirical evidence to support the signalling function of dividends. Since managers have more information about the health of the company, dividend increases signal a healthy growing firm. An increase in dividend payout may be interpreted as the firm having good future profitability and therefore its share news will react positively. Asqiuth and Mullins (1983) find that the initiation of dividend has significant positive impact on the firm's stock price. The positive relation between dividend policy and stock prices was also shown by John and Williams (1985). Consequently if a more profitable firm pays a higher dividend, investors would buy that stock and drive its price high.

Dividend payouts not only enhance firm values owing to their information content but if investors perceive high dividend paying companies as less risky it will also result in lower 
cost of equity/required returns. This will positively impact firm values as one can see from the valuation equation

$$
\mathrm{V}=\frac{\overline{\mathrm{x}}}{\mathrm{k}}
$$

where $\overline{\mathrm{X}}$ is the expected stream of dividends/cash flows to infinity, $\mathrm{k}$ is the cost of equity/ required returns of investors and $\mathrm{V}$ is the equity value.

That investors perceive high dividend paying companies as less risky is reconfirmed by evidence in the literature on relationship between dividend payments and market beta. Several studies have explored the relationship of dividends payouts with market beta. Logue and Merville (1972) documented that investors are assured of the flow of returns from dividend payouts than the flow of returns obtained from higher stock prices. This leads to the inverse relationship between payouts and beta. Beaver, Kettler and Scholes (1970) assert that ceteris paribus firms with lower payout ratios are more risky. This is because payout ratio shows the management's perception of uncertainty with respect to firm's earnings. Breen and Lernen (1973) and $\mathrm{Gu}$ and Kim (2002) purport an inverse relationship between systematic risk and high dividend payout. This would mean that higher dividend paying firms are less risky and hence investors demand a lower premium. Thus we have a counter argument which states that high profitable firms pay higher dividends which are viewed as less risky by the investors and hence they are willing to accept lower returns.

This paper has been motivated by the following research gaps. Firstly a study of the profitability anomaly in the Indian stock market thus far has not been conducted. Secondly the anomaly for the mature markets has been analysed from the point of view of the firm and not the investor. To fill this void in the literature this paper examines the profitability anomaly in the Indian stock market, investigates the reasons for its existence and explores possible explanations. We specifically examine the following propositions

- What is the relationship between firm profitability and stock returns?

- Do more profitable firms pay higher dividends?

- Can profitability anomaly be explained by CAPM based market factor and therefore does the slope of the market factor bear a relation with dividend payouts?

- Can the Fama French multi factor model explain returns that are possibly missed by CAPM?

- Are there any links between Fama French size and value factors and firm payouts?

The objectives of the study are

1. Is the profitability anomaly in returns empirically validated in Indian context?

2. Does the relationship between profitability and returns reflect firm or investor perspective? 
3. Can the profitability anomaly be captured by standard asset pricing models such as CAPM and Fama French?

4. Do the risk factors bear a fundamental relation with corporate payouts?

The paper is organised as follows. Section 2 describes the data and their sources. Section 3 explains the methodology followed. Section 4 gives the empirical results. The last section contains summary, policy implications and concluding remarks.

\section{Data}

The sample used consists of 493 companies that form part of BSE-500 equity index. The study uses month end closing adjusted share prices (adjusted for capitalisation such as bonus, rights and stock splits) from Jan 1996 to Dec 2010 (180 monthly observations). BSE-500 index represents nearly $93 \%$ of the total market capitalization on BSE, accounts for $95 \%$ of trading activity, and covers all 20 major industries of the economy. Hence the sample is fairly representative of market performance. The Bombay Stock Exchange (BSE) -200 index is used as the market proxy. It is a broad based value weighted index which is constructed on the lines of S\&P500 (USA). The month end share price series have been converted into percentage return series for further estimation.

Market capitalisation is used as the size proxy. It is calculated as the natural log of price times shares outstanding. Price to book (inverse of BE/ME) is used as the value proxy. Price to book value per share represents the security price over a company's book value. We use two alternative measures for profits viz return on equity and return on assets. Return on equity is calculated as the income available to common stockholders for the most recent fiscal year divided by the average common equity. Return on assets is calculated as net income scaled by average total assets.

Data on share prices, market index all company characteristics has been obtained from the Thomsonone database of Thomson Reuters. The implicit yields on 91-day treasury bills have been used as risk-free proxy as is the standard practice in finance literature. The data for this has been obtained from the RBI monthly handbook of statistics.

We use the firm's dividend payout ratio to represent the dividend decision. Dividends payout ratio is calculated as equity dividend that is paid to equity share owners as a percentage of total profit after tax. Data on this has been obtained from CMIE-Prowess.

\section{Methodology}

\subsection{Test the relation between profitability and returns}

We form single sorted portfolios based on each measure of profitability. In December of year $\mathrm{t}-1$, the securities are ranked on the basis of the profitability definition under consideration. The ranked securities are then classified into five portfolios P1 to P5 and equally-weighted monthly excess returns are estimated for these portfolios for the next 12 months (t). P1 is the portfolio consisting of $20 \%$ of companies with lowest attribute while P5 consists of top 20\% companies with highest attribute under consideration. P1 and P5 are referred henceforth as 
corner portfolios in the study. The portfolios are re-balanced at the end of December of year $t$. We define a year as calendar year from January to December. Sample securities are sorted in December of each year beginning in December 1995 and portfolio formation process repeated till we reach December 2009.

In the first step of our methodology we observe the unadjusted mean excess returns across the portfolios created, and ascertain the relationship between profitability and returns.

\subsection{Relationship between profitability and payouts}

To estimate relationship between dividend payouts and profitability we run a panel OLS regression where the dividend payout is the dependent variable and the explanatory variable is profits. We estimate the following equation

$$
\text { Payout }_{\mathrm{i}, \mathrm{t}}=\lambda_{0}+\lambda_{1} \text { profits }_{\mathrm{i}, \mathrm{t}}+\varepsilon_{\mathrm{t}}
$$

where $\lambda_{0}$ is a constant. A significant positive value of $\lambda_{1}$ would indicate that more profitable firms pay higher dividends and vice versa. To confirm these results we also constructed profitability sorted portfolios and calculated the average payout ratios of the corner portfolios.

\subsection{Asset pricing test - CAPM}

CAPM regressions are run on each of the five portfolios using the familiar "excess return" version of the market model equation.

$$
\mathrm{R}_{\mathrm{pt}}-\mathrm{R}_{\mathrm{ft}}=\mathrm{a}+\mathrm{b}\left(\mathrm{R}_{\mathrm{mt}}-\mathrm{R}_{\mathrm{ft}}\right)+\mathrm{e}_{\mathrm{t}}
$$

where $R_{p t}-R_{f t}$ is the monthly excess return on the portfolio i.e. return on portfolio $P$ minus risk free return $\left(\mathrm{R}_{\mathrm{ft}}\right)$,

$\mathrm{R}_{\mathrm{mt}}-\mathrm{R}_{\mathrm{ft}}$ is the excess market return i.e return on market factor minus risk free return,

$\mathrm{e}_{\mathrm{t}}$ is the error term,

a (intercept) is a measure of abnormal profits and

$\mathrm{b}$ is the sensitivity coefficient of market factor.

The CAPM implies that excess returns on a portfolio should be fully explained by excess market returns. Hence, the expected value of a (the intercept term) should be 0 . A significantly positive (negative) value of 'a' (intercept) implies extra-normal profits (losses). If there is a significant positive or negative intercept in the CAPM specification, then a CAPM anomaly exists.

\subsection{Relation between beta and payouts}

The purpose of estimating the relation between beta and payouts is to evaluate if high payout firms are perceived to be less risky by investors. We first estimate stock beta for each individual firm by regressing a firm's excess monthly stock return against the excess market return using rolling three year regressions over the entire time period. The variable beta 


\section{Macrothink

measures the co movement of security return with the market return and is called the systematic risk of the equity security of firm $i$. The value of $\beta i$ is obtained from the following time series regression for each firm in the sample as follows

$$
\mathrm{Y}_{\mathrm{i}}=\alpha+\beta_{\mathrm{i}} \mathrm{X}
$$

where $Y_{i}$ is the excess monthly return of a firm $i$,

$\mathrm{X}$ is the excess market return,

$\alpha$ the intercept and $\beta_{\mathrm{i}}$ (beta) is the stock beta for firm $\mathrm{i}$.

Once the value of beta is available for each firm over the entire sample period, we estimate the relation between beta and payouts using panel OLS in the following equation

$$
\text { beta }_{\mathrm{i}, \mathrm{t}}=\gamma_{0}+\gamma_{1} \text { payouts } \mathrm{i}_{\mathrm{t}}+\varepsilon_{\mathrm{t}}
$$

where beta is the estimated yearly beta from equation 4 and $\gamma_{0}$ is the intercept. The value of $\gamma_{1}$ in this equation shows the relationship between beta and payouts. To confirm our results on relationship between beta and payouts, we constructed portfolios on the basis of payouts and calculated the average betas of the corner portfolios.

\subsection{Asset pricing test-Fama French (FF) model}

If a CAPM anomaly exists then we attempt to evaluate if the excess returns of the stylized portfolios that are missed by CAPM can be explained using the three factor model of Fama and French (1993) specified as follows. .

The FF Model is given by:

$$
R_{p t}-R_{f t}=a+b\left(R_{m t}-R_{f t}\right)+s\left(S_{\text {MB }}\right)+h\left(L M H_{t}\right)+e_{t}
$$

Where $\mathrm{SMB}_{\mathrm{t}}$ is the monthly return on the size mimicking portfolio,

$\mathrm{LMH}_{\mathrm{t}}$ is the monthly return on the price-to-book mimicking portfolio,

$\mathrm{s}$ and $\mathrm{h}$ are the sensitivity coefficients of $\mathrm{SMB}_{\mathrm{t}}$ and $\mathrm{LMH}_{\mathrm{t}}$

The other two terms are same as defined in equation (3).

We estimate the SMB and LMH as follows. In each year of the sample period t, the stocks are split into two groups- big (B) and small (S) - based on whether their market capitalization at the end of December of every year in the sample period is above or below the median for the stocks of the companies included. The price to book equity ratio is calculated in this month for all the companies. The stocks are now split into two equal $\mathrm{P} / \mathrm{B}$ groups. Then we construct four portfolios viz. $\mathrm{S} / \mathrm{L}, \mathrm{S} / \mathrm{H}, \mathrm{B} / \mathrm{L}, \mathrm{B} / \mathrm{H}$. from the intersection of the two size and two $\mathrm{P} / \mathrm{B}$ groups. Monthly equally weighted return series are calculated for all portfolios from Jan of year $\mathrm{t}$ to December of year $\mathrm{t}$. 


\section{Macrothink Institute $^{\text {TM }}$}

The Fama and French model uses three explanatory variables for explaining the cross section of stock returns ${ }^{2}$. The first factor is the excess market return which is the market index return minus the risk-free return. The second is the risk factor in returns relating to size - small minus big (SMB). To calculate the monthly return of the SMB factor we subtract the simple average of the monthly returns of the two big size portfolios $(\mathrm{B} / \mathrm{L}, \mathrm{B} / \mathrm{H})$ from the average of the two small size portfolios $(\mathrm{S} / \mathrm{L}, \mathrm{S} / \mathrm{H})$ as this factor has about the same weighted-average price to book it is free from value effects.

$$
\mathrm{SMB}=(\mathrm{S} / \mathrm{L}+\mathrm{S} / \mathrm{H}) / 2-(\mathrm{B} / \mathrm{L}+\mathrm{B} / \mathrm{H}) / 2
$$

The third factor is $\mathrm{LMH}_{\mathrm{t}}$ which is related to value. It is constructed as follows such that it is independent of size factor.

$$
\mathrm{LMH}=(\mathrm{S} / \mathrm{L}+\mathrm{B} / \mathrm{L}) / 2-(\mathrm{S} / \mathrm{H}+\mathrm{B} / \mathrm{H}) / 2
$$

If the intercepts from the FF regressions are insignificant and the intercepts from the CAPM regressions are significant, then this implies that the FF specification is able to capture cross sectional patterns in average stock returns that are missed by CAPM. Greater sensitivity of sample portfolio returns to the size and value risk factors is shown by higher factor loadings i.e $\mathrm{s}$ and $\mathrm{h}$ for these factors. We further verify if the corner portfolios (P1 and P5) comprise of stocks with particular attributes i.e. small (big) size, low (high) P/B ratio. Such stock characteristic patterns in the sample portfolios shall support the strong performance if any of the FF model.

\subsection{Relationship between dividend payout, size and value factors}

We next evaluate if FF size and value factors have their tracks in firm payout ratios i.e. do small and low $\mathrm{P} / \mathrm{B}$ firms tend to pay lower dividends and hence are perceived by investors to be more risky vis-a-vis big and high P/B firms. To estimate the relationship of size and value factors with dividend payouts respectively we estimate the two panel OLS as follows

$$
\begin{aligned}
& \text { Size }_{\mathrm{i}, \mathrm{t}}=\gamma_{0}+\gamma_{1} \text { payouts }_{\mathrm{i}, \mathrm{t}}+\varepsilon_{\mathrm{t}} \\
& \mathrm{P} / \mathrm{B}_{\mathrm{i}, \mathrm{t}}=\gamma_{3}+\gamma_{4} \text { payouts }_{\mathrm{i}, \mathrm{t}}+\varepsilon_{\mathrm{t}}
\end{aligned}
$$

where $\gamma_{0}$ and $\gamma_{3}$ are intercepts and $\gamma_{1}$ and $\gamma_{4}$ would indicate the relationship of size and value factors with dividends if any. To confirm these results we also construct portfolios based on size, $\mathrm{P} / \mathrm{B}$ and compute the average values of dividend payouts for corner portfolios.

\section{Empirical Results}

We begin the empirical results by estimating the relationship between profitability and unadjusted returns.

Table 1. Unadjusted average monthly excess returns on profitability sorted portfolios

Panel A. ROE sorted portfolios

\footnotetext{
${ }^{2}$ Construction methodology for size and value factors has been adopted from Sehgal, Subramaniam and Morandiere(2012).
} 


\begin{tabular}{|l|l|l|l|l|l|l|l|l|l|}
\hline \multicolumn{2}{|l|}{ P1 } & \multicolumn{2}{l|}{ P2 } & \multicolumn{2}{l|}{ P3 } & P4 & P5 \\
\hline Mean & $\begin{array}{l}\text { t- } \\
\text { stat }\end{array}$ & Mean & t-stat & Mean & t-stat & Mean & t-stat & Mean & $\begin{array}{l}\text { t- } \\
\text { stat }\end{array}$ \\
\hline 0.023 & 2.461 & 0.017 & 2.205 & 0.014 & 1.927 & 0.017 & 2.459 & 0.015 & 2.197 \\
\hline
\end{tabular}

Panel B. ROA sorted portfolios

\begin{tabular}{|l|l|l|l|l|l|l|l|l|l|}
\hline \multicolumn{2}{|l|}{ P1 } & \multicolumn{2}{l|}{ P2 } & \multicolumn{2}{l|}{ P3 } & P4 & P5 \\
\hline Mean & $\begin{array}{l}\text { t- } \\
\text { stat }\end{array}$ & Mean & t-stat & Mean & t-stat & Mean & t-stat & Mean & $\begin{array}{l}\text { t- } \\
\text { stat }\end{array}$ \\
\hline 0.026 & 2.789 & 0.032 & 3.141 & 0.021 & 2.554 & 0.019 & 2.648 & 0.015 & 2.215 \\
\hline
\end{tabular}

Table 1, Panel A shows that the unadjusted returns on ROE sorted portfolios are larger for less profitable stocks as compared to more profitable stocks. The return differential between less profitable and more profitable stocks is $1 \%$ per month ( $\mathrm{t}$-stat $=2.01$ ) which is about $12 \%$ p.a. and hence is robust. Panel B shows that sorting on ROA the average returns are again significantly higher for low profitability stocks as compared to that of high profitability stocks. The lowest profitability portfolio produces an abnormal return of $2.6 \%$ per month whereas the highest profitability portfolio produces an abnormal return of $1.5 \%$ per month. Thus we find a negative relation between profitability and returns which is in contrast to the results obtained for mature markets.

Is it possible that the Indian investor finds high profitable stocks to be less risky due to which he is willing to accept lower returns? To answer this question we want to explore the information contained in profits which could contribute to the risk argument. We visualise one risk factor which could be linked to dividend payouts. Hence we calculated the relation between profitability and payouts.

Table 2. Empirical results of the panel OLS regression of payouts on profitability.

Payout $_{\mathrm{i}, \mathrm{t}}=\beta_{0}+\beta_{1}$ profitability $_{\mathrm{i}, \mathrm{t}}+\varepsilon_{\mathrm{t}}$

\begin{tabular}{|l|l|l|l|l|l|l|l|}
\hline \multicolumn{4}{|c|}{ ROE } & \multicolumn{4}{c|}{ ROA } \\
\hline$\beta_{0}$ & $\mathrm{t}\left(\beta_{0}\right)$ & $\beta_{1}$ & $\mathrm{t}\left(\beta_{1}\right)$ & $\beta_{0}$ & $\mathrm{t}\left(\beta_{0}\right)$ & $\beta_{1}$ & $\mathrm{t}\left(\beta_{1}\right)$ \\
\hline $0.255^{*}$ & 38.475 & $0.032^{*}$ & 3.222 & $0.244^{*}$ & 18.16 & $0.231 *$ & 2.074 \\
\hline
\end{tabular}

*Denotes significance at the $5 \%$ level using a two tailed t-test

Results of panel OLS regression ${ }^{3}$ (table 2)show that firm with larger profits(both ROE and ROA) are more likely to pay higher dividends while companies that have comparatively lower profits would adopt lower payouts. The results appear to be consistent with the findings of other empirical studies (Baker, Farrelly \& Edelman RB, 1985, Pruitt \& Gitman, 1991). The average values of payouts calculated for corner portfolios sorted on profitability (both ROE and ROA) strengthen our results. We find that average payout for low ROE (ROA) sorted portfolio is $20.12 \%(18.01 \%)$ and for high ROE (ROA) sorted portfolio is

\footnotetext{
${ }^{3}$ The equation has been estimated using fixed effects panel OLS method, which has been chosen over the random effects method based on Wu-Hausman statistic.
} 
$29.67 \%(31.14 \%)$. Corporate dividend policy tends to vary directly with current profits. Current profits may contain information about future profits and hence large payouts may send a positive signal leading to stock price appreciation.

Table 3. Empirical results based on one factor CAPM

Panel a. ROE sorted portfolios

\begin{tabular}{|l|l|l|l|l|l|}
\hline Portfolio & A & B & t(a) & $t(b)$ & Adj. $\mathrm{R}^{2}$ \\
\hline P1 & 0.012 & 1.166 & 2.078 & 17.810 & 0.638 \\
\hline P2 & 0.007 & 1.086 & 1.817 & 23.961 & 0.762 \\
\hline P3 & 0.004 & 1.026 & 1.240 & 23.269 & 0.751 \\
\hline P4 & 0.007 & 0.961 & 2.374 & 24.803 & 0.774 \\
\hline P5 & 0.006 & 0.988 & 2.008 & 30.003 & 0.833 \\
\hline
\end{tabular}

Panel B. ROA sorted portfolios

\begin{tabular}{|l|l|l|l|l|l|}
\hline Portfolio & A & B & t(a) & $t(b)$ & Adj. $\mathrm{R}^{2}$ \\
\hline P1 & 0.014 & 1.177 & 2.485 & 18.223 & 0.664 \\
\hline P2 & 0.020 & 1.124 & 2.810 & 13.681 & 0.527 \\
\hline P3 & 0.009 & 1.125 & 2.300 & 23.582 & 0.768 \\
\hline P4 & 0.009 & 0.994 & 2.635 & 26.171 & 0.803 \\
\hline P5 & 0.004 & 0.930 & 1.69 & 27.33 & 0.816 \\
\hline
\end{tabular}

CAPM results (Table 3) show that the extra normal returns (after adjusting for market risk) on ROE sorted portfolios is $1.2 \%$ per month for less profitable stocks and $\mathbf{0 . 6 \%}$ per month for more profitable stocks. The significant intercepts of corner portfolios confirm the presence of a profitability anomaly within the CAPM framework. We however find that the market beta for less profitable stocks(P1) is higher as compared to more profitable stocks(P5), showing that less profitable firms are more risky. The beta coefficient of both portfolios is also statistically significant which means that the market return factor is important in capturing a large amount of variation in common stock returns. We find that the alphas of P1 and P5 have sobered down due to the contribution of beta. Results on ROA sorted portfolios are in line with that obtained for ROE. The extra normal return (after adjusting for market risk) is $1.4 \%$ per month for less profitable stocks and $0.4 \%$ per month for more profitable stocks. The intercept of the lower profitability portfolio (P1) is statistically significant confirming the presence of a profitability anomaly within the CAPM framework. We reconfirm that market factor is able to explain part of the profitability anomaly. These results are in line with Louge and Merville (1972) who find negative relation between profitability and beta. They reason that investors perceive profitability as an "inverse surrogate" of business risk. Previous findings of Scherrer and Mathison (1996), Gu and Kim (2002) and Lee and Jang (2006) indicated a negative relationship between profitability and systematic risk.. From an investors perspective who is developing a trading strategy a highly profitable firm is less risky and hence should provide less returns. 
Table 4. Empirical results of the panel OLS regression of beta on dividend payouts beta $_{\mathrm{i}, \mathrm{t}}=\gamma_{0}+\gamma_{1}$ payouts $_{\mathrm{i}, \mathrm{t}}+\varepsilon_{\mathrm{t}}$

\begin{tabular}{|l|l|l|l|l|}
\hline$\gamma_{0}$ & $\mathrm{t}\left(\gamma_{0}\right)$ & $\gamma_{1}$ & $\mathrm{t}\left(\gamma_{1}\right)$ & Adj. $^{2}$ \\
\hline $0.967^{*}$ & 20.949 & $-0.074^{*}$ & -3.235 & 0.002 \\
\hline
\end{tabular}

*Denotes significance at the 5\% level using a two tailed t-test

The results of panel $\mathrm{OLS}^{4}$ show that market beta is significantly negatively related to dividend payouts (table 4). Firms with high payouts (profitability) are perceived to be less risky investments while firms with persistently low payouts (profitability) are perceived to be more risky. This is expected as firms which are less profitable and hence do not have adequate funds resulting in low/no dividends are typically more risky (higher beta). We find that since beta shows a negative link with payouts, it absorbs a portion of returns in CAPM.

Table 5. Empirical Results for the three factor Fama French Model based on Market, Size \& Value factors.

Panel a.ROE sorted portfolios

\begin{tabular}{|l|l|l|l|l|l|l|l|l|l|}
\hline Portfolio & A & B & S & H & $\mathrm{t}(\mathrm{a})$ & $\mathrm{t}(\mathrm{b})$ & $\mathrm{t}(\mathrm{s})$ & $\mathrm{t}(\mathrm{h})$ & Adj. $^{2}$ \\
\hline P1 & -0.0053 & 1.066 & 0.686 & 0.522 & -0.120 & 20.983 & 7.794 & 5.759 & 0.791 \\
\hline P2 & 0 & 1.024 & 0.415 & 0.322 & -0.108 & 26.944 & 6.302 & 4.742 & 0.839 \\
\hline P3 & -0.002 & 0.969 & 0.420 & 0.284 & -0.801 & 26.057 & 6.530 & 4.277 & 0.830 \\
\hline P4 & 0.002 & 0.927 & 0.324 & 0.137 & 0.878 & 25.952 & 5.248 & 2.159 & 0.816 \\
\hline P5 & 0.001 & 0.997 & 0.420 & -0.269 & 0.609 & 35.901 & 8.748 & -5.433 & 0.886 \\
\hline
\end{tabular}

Panel b. ROA sorted portfolios

\begin{tabular}{|l|l|l|l|l|l|l|l|l|l|}
\hline Portfolio & A & B & S & H & $t(a)$ & $t(b)$ & $t(s)$ & $t(h)$ & Adj. ${ }^{2}$ \\
\hline P1 & 0.002 & 1.084 & 0.523 & 0.554 & 0.367 & 20.776 & 5.821 & 5.931 & 0.789 \\
\hline P2 & -0.003 & 0.965 & 1.090 & 0.827 & -0.780 & 23.239 & 15.234 & 11.108 & 0.884 \\
\hline P3 & 0 & 1.070 & 0.502 & 0.210 & 0.085 & 26.922 & 7.333 & 2.950 & 0.845 \\
\hline P4 & 0.002 & 0.961 & 0.371 & 0.082 & 0.809 & 28.403 & 6.370 & 1.350 & 0.850 \\
\hline P5 & 0 & 0.927 & 0.429 & -0.224 & 0.120 & 32.142 & 8.626 & -4.341 & 0.873 \\
\hline
\end{tabular}

The FF results (Table 5) show insignificant intercepts for lowest profitability portfolios(both ROE and ROA) owing to contribution of both size and value factors. FF regressions show that both SMB and LMH coefficients are higher for P1 as compared to P5 confirming role of size and value factors in explaining profitability based returns. The alpha of P1 is predominantly captured by value factor and marginally by size factor. Hence the three factor model absorbs the profitability sorted returns that are missed by CAPM. Further FF results are robust to choice of profitability proxy i.e. ROE and ROA.

4 The equation has been estimated using random effects panel OLS method, which has been chosen over the fixed effects method based on Wu-Hausman statistic. 
When we investigate the average size and $\mathrm{P} / \mathrm{B}^{5}$ for the profitability sorted portfolios (both ROE and ROA) we find that P1 is actually small size and low P/B vis-a-vis P5 i.e. less profitable firms are relatively distressed and smaller in size (for use of $\mathrm{P} / \mathrm{B}$ as a measure of relative distress see Chan and Chen(1991)). Since less profitable firms are relatively distressed and small in size, it is found that small sized companies and low P/B companies give lower dividend payouts and hence are perceived to be more risky by investors.

Next we try to develop a risk story for size and value factors.

Table 6. Empirical results of panel OLS regression of size on dividend payouts and value on dividend payouts

Size $_{\mathrm{i}, \mathrm{t}}=\gamma_{0}+\gamma_{1}$ payouts $_{\mathrm{i}, \mathrm{t}}+\varepsilon_{\mathrm{t}}$

$\mathrm{P} / \mathrm{B}_{\mathrm{i}, \mathrm{t}}=\gamma_{3}+\gamma_{4}$ payouts $_{\mathrm{i}, \mathrm{t}}+\varepsilon_{\mathrm{t}}$

\begin{tabular}{|l|l|l|l|l|l|l|l|l|l|}
\hline$\gamma_{0}$ & $\mathrm{t}\left(\gamma_{0}\right)$ & $\gamma_{1}$ & $\mathrm{t}\left(\gamma_{1}\right)$ & $\begin{array}{l}\text { Adj } \\
\mathrm{R}^{2}\end{array}$ & $\gamma_{3}$ & $\mathrm{t}\left(\gamma_{3}\right)$ & $\gamma_{4}$ & $\mathrm{t}\left(\gamma_{4}\right)$ & Adj. $\mathrm{R}^{2}$ \\
\hline 22.817 & 609.45 & 0.125 & 1.96 & 0.001 & 3.13 & 3.904 & 0.989 & 0.782 & 0 \\
\hline
\end{tabular}

Our panel OLS results (table 6) show weak positive relationship between firm size and payouts and a weak positive relationship between $\mathrm{P} / \mathrm{B}$ and payouts. Examining the corner portfolios formed on the basis of size and $\mathrm{P} / \mathrm{B}$ it is observed that small and low $\mathrm{P} / \mathrm{B}$ firms do exhibit lower payouts vis-a-vis big and high $\mathrm{P} / \mathrm{B}$ firms (average payouts for small firms is $19.17 \%$ and for big firms is $30.15 \%$. Average payouts for low $\mathrm{P} / \mathrm{B}$ firms is $20.26 \%$ and for high $\mathrm{P} / \mathrm{B}$ firms is $30.64 \%$ ). However in the absence of any statistically significant relationship one might infer that there could be other reasons for the risk story leading to these factors for instance small firms are exposed to high operational, financial risks owing to the nature of their business and more liquidity risk owing to investor neglect. Low P/B stocks on the other hand represent relatively distressed firms as show by weaker track record of their past sales and earnings growth rates (see Fama and French (1995)).

\section{Summary and Conclusions}

Prior research has confirmed a positive relation between profitability and returns for mature markets (see Fama and French (2008)). These results can be explained if we look at the issue from entrepreneur's perspective thus treating profits as a reward for risk bearing.

Our results however confirm a negative relation between profitability and returns which is robust to choice of profitability measure. This could possibly be explained by examining the problem from investor's perspective. More profitable firms tend to pay higher dividends and therefore are perceived to be less risky by investors. Thus a negative relation is postulated between dividend payouts and firm betas. In other words more profitable (and higher payout) firms should provide lower returns. It is equally important to know whether profitability based anomalous pattern in returns could be explained by standard asset pricing models. One

\footnotetext{
${ }^{5}$ For ROE (ROA) sorted portfolios the average values of market cap (size) for P1 is 22.42 (22.53) and for $\mathrm{P} 5$ is 22.53(23.92).For ROE (ROA) sorted portfolios the average values of $\mathrm{P} / \mathrm{B}$ for $\mathrm{P} 1$ is $-0.87(-0.88)$ and for $\mathrm{P} 5$ is $8.09(8.81)$.
} 
factor CAPM is partially able to explain the alphas on profitability sorted portfolios. Dividend payouts confirm the risk argument for the market factor as a negative relationship between payout and beta is empirically confirmed.

It is further found that the FF size and value based factors absorb the profitability based returns that are missed by CAPM. Hence the profitability anomaly does not pose an empirical challenge to multifactor asset pricing framework in Indian context. These risk factors however do not bear significant relationship with payout ratios, thus suggesting that alternative explanations might be needed to justify their risk premiums.

The study has strong implications for academicians who are searching for a rational asset pricing theory that can explain prominent equity market anomalies and has a universal appeal. There are also implications for investment managers who are continuously in pursuit of profitable style based trading strategies.

The present research contributes to asset pricing anomaly literature especially for emerging markets.

\section{References}

Ahmed, H., \& Javid, A. (2009). Determinants of dividend policy in Pakistan. International research journal of finance and economics, 29, 110-125.

Aivazian, V., Booth, L., \& Cleary, S. (2003). Do emerging market firms follow different dividend policies from US firms?. Journal of financial research, 26, 371-387. http://dx.doi.org/10.1111/1475-6803.00064

Amidu, M., \& Abor, J. (2006). Determinants of dividend payout ratios in Ghana. The journal of risk finance, 7(2), 136-145. http://dx.doi.org/10.1108/15265940610648580

Artmann, S., Finter, P., \& Kempf, A. (2011). Determinants of expected stock returns:large sample evidence from the german market. CFR working paper, 10-01.

Asquith, P., \& Mullins, D. (1983). The impact of initiating dividend payments on shareholder's wealth. Journal of business, 56, 1-12. http://dx.doi.org/10.1086/296187

Baker , H., Farrelly , G., \& Edelman RB, H. (1985). A survey of management views on dividend policy. Financial Management, 14(3), 1007-34. http://dx.doi.org/10.2307/3665062

Banz, Rolf W. (1981).The Relationship between Return and Market Value of Common Stock. Journal of Financial Economics, March(3-18). http://dx.doi.org/10.1016/0304-405X(81)90018-0

Basu, Sanjoy. (1983). The Relationship Between Earnings Yield, Market Value and Return for NYSE Common Stocks: Further Evidence. Journal of Financial Economics, 12, 129-156. http://dx.doi.org/10.1016/0304-405X(83)90031-4

Beaver, W., Kettler, P., \& Scholes, M. (1970). Marketing and accounting determined risks. The accounting review, 654-682. 
Bhandari, L. C. (1988). Debt-Equity Ratio and Expected Common Stock Returns: Empirical Evidence. Journal of Finance, 43,507-528. http://dx.doi.org/10.1111/j.1540-6261.1988.tb03952.x

Breen, W., \& Lerner, E. (1973). Corporate financial strategies and market measures of risk and return. The journal of finance, 28(2), 339-351. http://dx.doi.org/10.1111/j.1540-6261.1973.tb01777.x

Chan, K.C., \& Chen, Nai-Fu. (1991). Structural and return characteristics of small and large firms. Journal of finance, 56(4), 1467-1484.

Cohen, R. B., Gompers, P. A., \& Vuolteenaho, T. (2002). Who underreacts to cashflow. $\begin{array}{llll}\text { Journal of Financial } & \text { Economics, }\end{array}$ http://dx.doi.org/10.1016/S0304-405X(02)00229-5

De Bond, W.F., \& Thaler, R. (1985). Do the stock markets overreact?. Journal of Finance, 40, 793-805. http://dx.doi.org/10.1111/j.1540-6261.1985.tb05004.x

De Bondt, W.F., \& Thaler, R. (1987). Further evidence of investor overreaction and stock market seasonality. Journal of Finance, 42, 557-581. http://dx.doi.org/10.1111/j.1540-6261.1987.tb04569.x

Fama, Eugene F., \& French, Kenneth R. (1992). The cross-section of expected returns. Journal of Finance, 47, 427-466. http://dx.doi.org/10.1111/j.1540-6261.1992.tb04398.x

Fama, Eugene F., \& French, Kenneth R. (1993). Common risk factors in the returns on stocks and bonds. Journal of Financial Economics, 33, 3-56. http://dx.doi.org/10.1016/0304-405X(93)90023-5

Fama, E., \& French, K. (1995). Size and book to market factors in earnings and returns. Journal of finance, 50(1), 131-155. http://dx.doi.org/10.1111/j.1540-6261.1995.tb05169.x

Fama, Eugene F., \& French, Kenneth R. (1996). Multi-factor expalnation of asset pricing anomalies. Journal of Finance, 55-84. http://dx.doi.org/10.1111/j.1540-6261.1996.tb05202.x

Fama, E., \& French, K. (2006). Profitability, investment and average returns. Journal of financial economics, 82, 491-518. http://dx.doi.org/10.1016/j.jfineco.2005.09.009

Fama, Eugene F., \& French, Kenneth R. (2008).Dissecting Anomalies. Journal of Finance, 63(4), 1653-1678.

Fitzpatrick, J., \& Ogden, J. (2009). Do asset pricing anomalies have a common link?. Retrieved from http://ssrn.com/abstract=1364888Gordon, M. (1963). Optimal investment and financing policy. Journal of finance, 2, 264-272.

Gu, Z., \& Kim, H. (2002). Determinants of restaurant systematic risk: A reexamination. Journal of hospitality financial management, 10(1), 1-13. 
Haugen, R. A., \& Nardin, L. Baker. (1996). Commonality in the determinants of expected stock. Journal of Financial Economics, 41, 401-439. http://dx.doi.org/10.1016/0304-405X(95)00868-F

Ikenberry, D., Lakonishok, J., \& Vermaelen, T. (1995). Market underreaction to open market share repurchases. Journal of Financial Economics, 39, 181-208. http://dx.doi.org/10.1016/0304-405X(95)00826-Z

Jegadeesh, N., \& Titman, S. (1993). Returns to buying winners and selling losers: implications for stock market efficiency. Journal of finance, 48, 65-91. http://dx.doi.org/10.1111/j.1540-6261.1993.tb04702.x

John, K., \& Williams, J. (1985). Dividends, dilution and taxes:a signalling equilibrium. The journal of finance, 40(4), 1053-1070

Lee, J., \& Jang, S. (2007). The systematic-risk determinants of the US airline industry. Tourism management, 28, 434-442. http://dx.doi.org/10.1016/j.tourman.2006.03.012

Logue.D. E., \& Merville. L. J, (1972). Financial policy and market expectations. Financial management, 1(3), 37-44. http://dx.doi.org/10.2307/3665142

Loughran, T., \& Ritter, J. R. (1995). The new issues puzzle. Journal of Finance, 50, 23-51. http://dx.doi.org/10.1111/j.1540-6261.1995.tb05166.x

Pruitt, S., \& Gitman, L. (1991). The interactions between the investment, financing and dividend decisions of major us firms. Financial Review, 26(33), 409-30. http://dx.doi.org/10.1111/j.1540-6288.1991.tb00388.x

Schemer, P., \& Mathison, T. (1996). Investment strategies for REIT investors. Real estate review, 26(I), 5-10.

Schwert, W. G. (2003). Anomalies and market efficiency. In Constantinides, M. Harris and R. Stultz (Eds.), Handbook of the economics of finance (pp. 939-947).

Sehgal, S., Subramaniam, S., \& Morandiere, L. P. (2012). A search for rational sources of stock return anomalies:evidence from India. International Journal of Economics and Finance, 4(4), 121-134. http://dx.doi.org/10.5539/ijef.v4n4p121

Shefrin, H., \& Statman, M. (1984). Explaining invetsor preference for cash dividends. $\begin{array}{llll}\text { Journal of financial economics, } & 1984(13),\end{array}$ http://dx.doi.org/10.1016/0304-405X(84)90025-4

Sloan, R. (1996). Do stock prices fully reflect information in accruals and cash flows about future earnings?. The Accounting Review, 71, 289-315

Stattman, D. (1980).Book Values and Stock Returns, The Chicago MBA - A Journal of Selected Papers, 4:25-45.

Yiadom, E. M., \& Agyei, S. K. (2011). Determinants of dividend policy of banks in Ghana. International journal of finance and economics, 61, 99-108. 